\title{
Application of horse-derived placental peptides in cosmetics
}

\author{
Koji Wakame $^{1 *}$, Akifumi Nakata ${ }^{1}$, Keisuke Sato ${ }^{1}$, Ken-Ichi Komatsu ${ }^{1}$ and Teruo Maruta ${ }^{2}$ \\ ${ }^{1}$ Faculty of Pharmaceutical Sciences, Hokkaido University of Science, Japan \\ ${ }^{2}$ C.B.S Inc., Japan
}

\begin{abstract}
The placenta is a tissue mass formed in the uterus. It is an indispensable organ that is responsible for the transportation of blood required for fetal growth. Horse placenta has been used in the health food and cosmetic fields in recent years. We enzymatically treated horse placenta and obtained placental peptides with molecular weights $<3,000 \mathrm{Da}$. We mainly performed the in vitro experiments using human fibroblasts. We confirmed that placental peptides primarily activate the mitochondria of human fibroblasts and promote the production of type I collagen. Therefore, we suggest the use of placental peptides as materials that contribute to the improvement of skin elasticity and reduction of wrinkles in the cosmetic field.
\end{abstract}

\section{Introduction}

Historically, "Shikasya," the human placenta, has been introduced as a traditional Chinese medicine with nourishing tonic effects. Under the initiative of the Japanese government, the development of "advanced nutrients" began in the 1940s in Japan. A group of obstetrics and gynecologists at Kyoto University School of Medicine have developed oral nutrients and injections from the human placenta that are still considered as pharmaceuticals [1-4]. Additionally, the placenta of some animals, including pigs, sheep, and horses, have been used as health foods and cosmetic ingredients in Japan and in other countries [5-9]. In the present study, we used placenta from thoroughbred horses that are popularly bred and reared in Hokkaido, Japan to obtain materials that could be applied in the cosmetic field. Presently, the methods mainly available in the market for processing placenta are enzymatic decomposition and high-pressure extraction methods. Our analysis has shown hydrolysis of proteins to amino acids in the placentas developed by many companies. In this study, we decomposed horse-derived placenta using multiple proteolytic enzymes and succeeded in obtaining peptides with approximate average molecular weights $<3,000 \mathrm{Da}$. Unlike amino acids alone, peptides having multiple amino acids can be expected to exhibit a wide variety of physiological activities; therefore, we performed basic in vitro tests using human fibroblasts and three-dimensional human epidermal culture system to determine the applicability of these placental peptides to health foods and particularly cosmetics.

\section{Methods}

\section{Preparation and analysis of placental peptides}

Placenta was collected from thoroughbred horse, washed, and pulverized followed by enzymatic degradation using several peptidases. Next, the placental peptides were filtered and lyophilized. The molecular weight distribution of the resulting powder was measured by high performance liquid chromatography (HPLC, performed by Japan Food Research Laboratories, Japan). In addition, metabolic analysis of structural components was performed by capillary electrophoresis timeof-flight mass spectrometry (CE-TOFMS) and liquid chromatography time-of-flight mass spectrometry (LC-TOFMS, performed by Human Metabolome Technologies Inc., Japan).
Analysis of the DPPH radical scavenging activity of placental peptides

After $200 \mu \mathrm{L}$ of an analytical sample solution containing horse placental peptides and $800 \mu \mathrm{L}$ of $0.1 \mathrm{M}$ Tris- $\mathrm{HCl}$ buffer $(\mathrm{pH}$ 7.4) were added into a test tube, $1 \mathrm{~mL}$ of the 2,2-Diphenyl-1-picrylhydrazyl (DPPH) (Wako Pure Chemical Industries, Japan) solution was added and left at room temperature in the dark for $30 \mathrm{~min}$. Exactly $30 \mathrm{~min}$ after the addition of the DPPH solution, the absorbance of the solution was measured at $517 \mathrm{~nm}$. A solution mixture of $1.2 \mathrm{~mL}$ of ethanol and $800 \mu \mathrm{L}$ of Tris- $\mathrm{HCl}$ buffer was used as the blank control. The absorbance at the addition of the analytical sample was termed $A_{1}$ and the absorbance at the time of ethanol addition instead of the sample was termed $\mathrm{A}_{2}$. The residual ratio of DPPH (\%) was obtained using the following equation:

$\mathrm{DPPH}$ residual ratio $(\%)=\left(\mathrm{A}_{1} / \mathrm{A}_{2}\right) \times 100$.

Measurement of the DPPH radical scavenging activity for the analytical sample solution was repeated three times at each concentration. Final concentrations of the analytical samples were 75 $\mu \mathrm{g} / \mathrm{mL}$ and $150 \mu \mathrm{g} / \mathrm{ml}$.

\section{Analysis of the effect of placental peptides on the mitochondria of human fibroblasts}

Normal human fibroblasts were purchased from Kurabo Industries Ltd. (Japan). Cells were grown to $80-90 \%$ confluence in Dulbecco's Modified Eagle Medium (DMEM) (Thermo Fisher Scientific, USA) containing 10\% fetal bovine serum (FBS) (Thermo Fisher Scientific, USA), $1 \%$ penicillin and streptomycin at $37^{\circ} \mathrm{C}$ in a humidified

*Correspondence to: Koji Wakame, Faculty of Pharmaceutical Sciences, Hokkaido University of Science, 15-4-1,Maeda 7-jo, Teine-ku, Sapporo-shi, Hokkaido 006-0085, Japan, Tel: +81(11) 676 8682; Fax: +81 (11) 676 8666; E-mail: wakame-k@hus.ac.jp

Key words: horse-derived placental peptides, fibroblasts, three-dimensional human epidermal culture system

Received: April 16, 2019; Accepted: April 26, 2019; Published: April 29, 2019 
atmosphere of $5 \% \mathrm{CO}_{2}$ and $95 \%$ air. Before treating the cells with placental peptides $(20-500 \mu \mathrm{g} / \mathrm{mL})$, the culture medium was replaced with DMEM containing $1 \%$ FBS. Peptides having average molecular weights of $8,000 \mathrm{Da}$ (Nippi high grade gelatin type AP, Nippi, Japan) and 60,000 Da (Nippi high grade gelatin APAT, Nippi, Japan) were used as controls.

Mito Tracker (Invitrogen, USA) staining was used to measure the number of mitochondria, whereas Rhodamine 123 (Funakoshi, Japan) and Hoechst 33342 (Dojindo, Japan) staining were used to measure mitochondrial activity. Hoechst 33342 (Ex: 340 nm, Em: $461 \mathrm{~nm}$ ), Mito Tracker (Ex: $579 \mathrm{~nm}$, Em: $599 \mathrm{~nm}$ ), and Rhodamine 123 (Ex: $505 \mathrm{~nm}$, Em: $534 \mathrm{~nm}$ ) stains were performed on days 3, 7, 14, and 21 after the initiation of cell culture. The fluorescence was measured using a microplate reader (Varioskan Flash, Thermo Fisher Scientific, USA). Fluorescence intensity values were normalized to the fluorescence intensity value of Hoechst stain to calculate the relative fluorescence value $(n=3)$. Quantity of mitochondrial analyses in cells were performed by BZ-X700 fluorescence microscope (Keyence, UK).

\section{Effect of horse placental peptides on type I collagen production of human fibroblasts}

Similar to mitochondrial activity experiments, normal human fibroblasts were cultured in 96-well plates in DMEM culture medium. Culture supernatants were collected on days 3, 7, 14, and 21 after the initiation of cell culture and stored at $-80^{\circ} \mathrm{C}$. Human type I collagen production was quantified using the Human Collagen type I, ELISA Kit (ACEL, Japan). The collagen concentration in the sample was calculated $(n=3)$ based on the standard curve obtained from the collagen standard stock solution, according to the manufacturer's instructions.

\section{Wound healing assay using human fibroblasts}

Normal human fibroblasts were seeded on 6-well plates and cultured as cell monolayers until they reached $80 \%$ confluency. A single cell layer was scratched using a $200 \mu \mathrm{L}$ pipette tip. Next, fibroblasts were cultured with placental peptides at a final concentration of 100 $\mu \mathrm{g} / \mathrm{mL}(\mathrm{n}=3)$. Digital photography was performed using an inverted microscope (CKX-41, Olympus, Japan) and a digital CCD camera (DP 72, Olympus, Japan) after culturing for 24 hours. The total migration distance of the cells across the scratched section was measured using the microscopy images.

\section{Influence of placental peptides on the three-dimensional human epidermal culture system}

Placental peptides were prepared at a concentration of $15 \%(\mathrm{~W} / \mathrm{V})$ and $50 \%(\mathrm{~W} / \mathrm{V})$ of that was added to a three-dimensional human epidermal culture system (Lab Cyte EPI-MODEL 24, J-TEC, Japan tissue engineering, Japan). As a cytotoxic substance control, 5\% (W/V) sodium lauryl sulfate (SLS) (Wako Pure Chemical Industries, Japan) was added to the same system $(n=3)$.

After 5 days in culture, cell viability was measured using the 3-(4,5-dimethylthial-2-yl)-2, 5-diphenyltetrazalium bromide (MTT, Wako Pure Chemical Industries, Japan) assay. The cells were then incubated with MTT, and the absorbance was measured at OD 540 $\mathrm{nm}$. After fixation in $10 \%$ formalin, hematoxylin and eosin staining was performed to observe the morphological changes of tissue structure in the three-dimensional human epidermal culture system using an optical microscope (Motic BA 300, Shimazu, Japan).

\section{Statistical analyses}

All results are expressed as means \pm standard error (S.E.) of the mean. Statistical significance was determined using the Dunnett's and Student's t-tests. All ${ }^{\star} \mathrm{p}<0.05,{ }^{\star *} \mathrm{p}<0.01$, or ${ }^{\star * *} \mathrm{p}<0.001$ was considered statistically significant.

\section{Results}

\section{Analysis of placental peptides}

Molecular weight analysis using HPLC showed that $72 \%$ of the placental peptides had approximate molecular weights of $<3,000 \mathrm{Da}$. Among them, $33 \%$ of peptides had molecular weights in the range 1,000-3,000 Da (Table 1). Metabolomic analysis of the structural components of these peptides using CE-TOFMS and LC-TOFMS showed 504 compounds, of which 320 were peptides, 70 were lipids, and approximately 40 were amino acid related compounds (Figures 1 and 2).

Table 1. Molecular weight distribution of horse-derived placental peptides. The molecular weight distribution of this powder was measured by high performance liquid chromatography (HPLC). Proteins are reduced into molecules by enzymatic reaction to give peptides, and the peptides are most frequently distributed between 1,000 and 3,000.

\begin{tabular}{|c|c|}
\hline Molecular weight & Peak area ratio (\%) \\
\hline$<6,000$ & 11 \\
\hline $3,000-6,000$ & 17 \\
\hline $1,000-3,000$ & 33 \\
\hline $500-1,000$ & 11 \\
\hline$<500$ & 28 \\
\hline Total & 100 \\
\hline
\end{tabular}

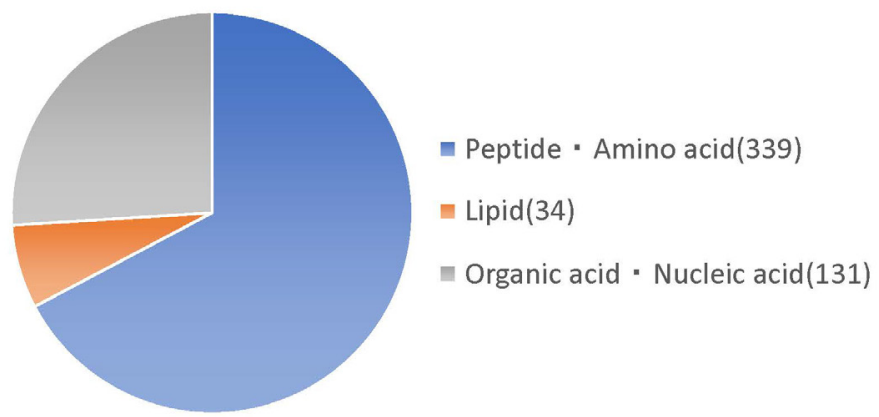

Figure 1. Nutritional analysis in planta peptides by metabolome analysis. Nutritional analysis of the placenta peptide confirmed peptides, lipids, organic acids and nucleic acids etc. Of the 339 peptides and amino acids, the number of peptides is 320 , excluding the amount of amino acids.

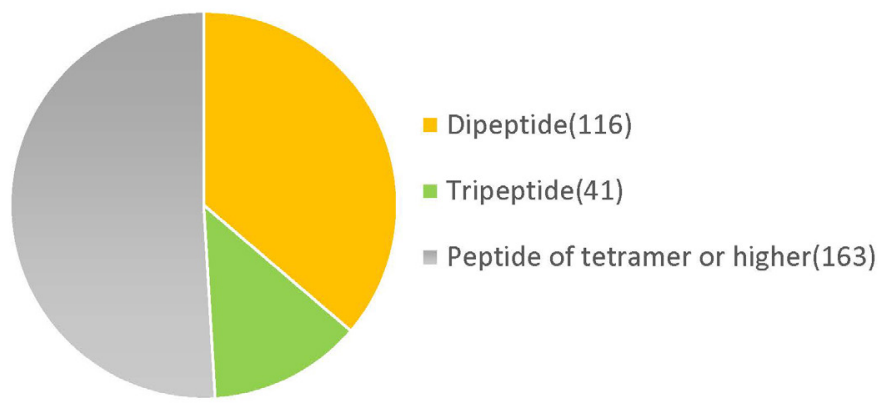

Figure 2. Low molecular peptides identification in placenta peptides by metabolome analysis. 


\section{DPPH radical scavenging activity of the placental peptides}

The results of the DPPH radical scavenging activity of the placental peptides are summarized in figure 3. The DPPH residual ratio was significantly reduced by placental peptides at final concentrations of 75 $\mu \mathrm{g} / \mathrm{mL}$ and $150 \mu \mathrm{g} / \mathrm{mL}$.

\section{Effect of placental peptides on the mitochondria of human} fibroblasts

The results of mitochondrial number evaluation using the Mito Tracker assay have been summarized in figures 4 and 5 . Addition of placental peptides significantly increased the number of mitochondria on day 3 of cell culture. Conversely, no activity was observed in the control group. Analysis of mitochondrial activity using Rhodamine and Hoechst staining of the fibroblasts on days 3, 7, 14, and 21 after the addition of placental peptides showed significantly enhanced mitochondrial activity in cells cultured for 7 days and above (Figure 6).

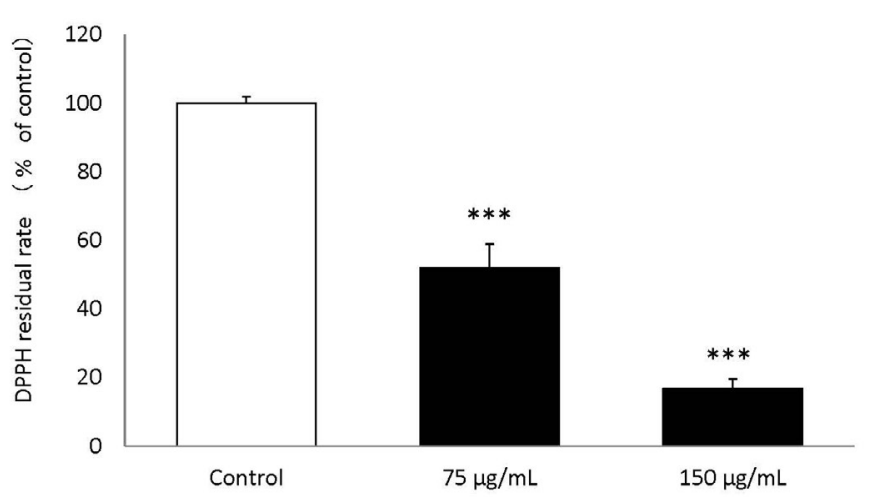

Figure 3. DPPH scavenging activity of placental peptides.

When Placenta peptides was added to the DPPH solution, the DPPH scavenging action was significant confirmed at a concentration of $75 \mu \mathrm{g} / \mathrm{mL}$ and $150 \mu \mathrm{g} / \mathrm{mL} . \mathrm{n}=3$, mean \pm s.d., Dunnett test, $* * * P<0.001$

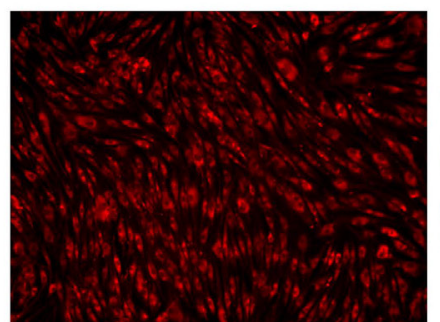

Control

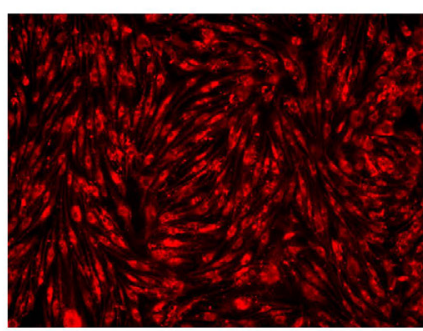

$100 \mu \mathrm{g} / \mathrm{mL}$

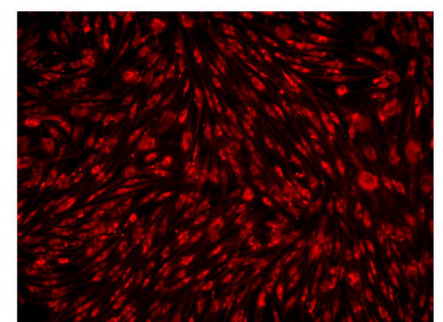

$20 \mu \mathrm{g} / \mathrm{mL}$

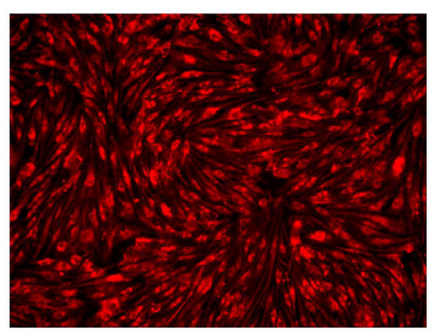

$500 \mu \mathrm{g} / \mathrm{mL}$
Figure 4. Photograph of mitochondrial amount in human fibroblasts by MitoTracker staining on 3 days culture.

\section{Effect of placental peptides on type I collagen production in} human fibroblasts

The results of type I collagen production are summarized in figure 7. Addition of placental peptides significantly elevated collagen production on days 14 and 21 of cell culture. On the other hand, no activity was observed in the control group. In order to eliminate the possibility of the presence of type I collagen in each test substance, we measured the level of type I collagen in the test medium containing the test substance in advance and did not detect type I collagen in any medium containing the test substance.

\section{Assessment of the effect of placental peptides on the wound healing ability of human fibroblasts}

In the wound healing test, the migration activity of fibroblasts was significantly enhanced by the addition of placental peptides (100 $\mu \mathrm{g} / \mathrm{mL}$ ). In comparison to the control group, an approximately $45 \%$ increase was observed in the migration ability of fibroblasts that were exposed to placental peptides (Figures 8 and 9).

Assessment of the effect of placental peptides on the threedimensional human epidermal culture system

MTT assay showed cell proliferation in the three-dimensional human epidermal culture system exposed to a placental peptide concentration of $15 \%(\mathrm{~W} / \mathrm{V})$ and $50 \%(\mathrm{~W} / \mathrm{V})$. In addition, 5\% SLS treatment reduced the number of cells by approximately $65 \%$ (Figures 10 and 11).

\section{Discussion}

In the present study, we investigated the possible application of horse placental peptides in cosmetics. Among the placental peptides obtained by enzymatic digestion, $33 \%$ had molecular weights in the range 1,000-3,000 $\mathrm{Da}$. Assuming that the average molecular weight of an amino acid is approximately $120 \mathrm{Da}$, it can be estimated that placental peptides are bound to 8-25 amino acids measured by metabolic analysis $[10,11]$. The presence of growth factors, such as the epidermal growth factor (EGF, molecular weight $\sim 6,200 \mathrm{Da}$ ) and fibroblast growth factor (FGF, molecular weight $\sim 17,000 \mathrm{Da}$ ), has been reported in the placenta. These growth factors are called oligopeptides $[12,13]$.

The development of functional peptides is a remarkable process. Octapeptide-24, acetyl decapeptide-3, and oligopeptide-20 are some of the peptides that have been developed based on EGF, FGF $[14,15]$, and insulin-like growth factor 1 (IGF-1), and they are expected to influence the growth of fibroblasts $[12,13]$. Conversely, owing to the species differences between horse-derived growth factors and human derived growth factors and the possibility of denaturation, degradation, and inactivation during the manufacturing process, it is unlikely that the remaining growth factors would have cosmetic effects. Our findings suggest that placenta peptides have more diverse physiological activities as a mixture of peptide bodies, even compared to proteins, high molecular weight peptides, and amino acids.

Mitochondria, an intracellular organelle of all human cells including fibroblasts, produce ATP, which provides the energy required for living organisms. Mitochondrial numbers and function have been reported to decrease with increasing age in humans [16]. Our findings show that addition of placental peptides to human fibroblasts increased the quantity and activity of mitochondria in the cell [17]. In addition, we show that placental peptides having unique 


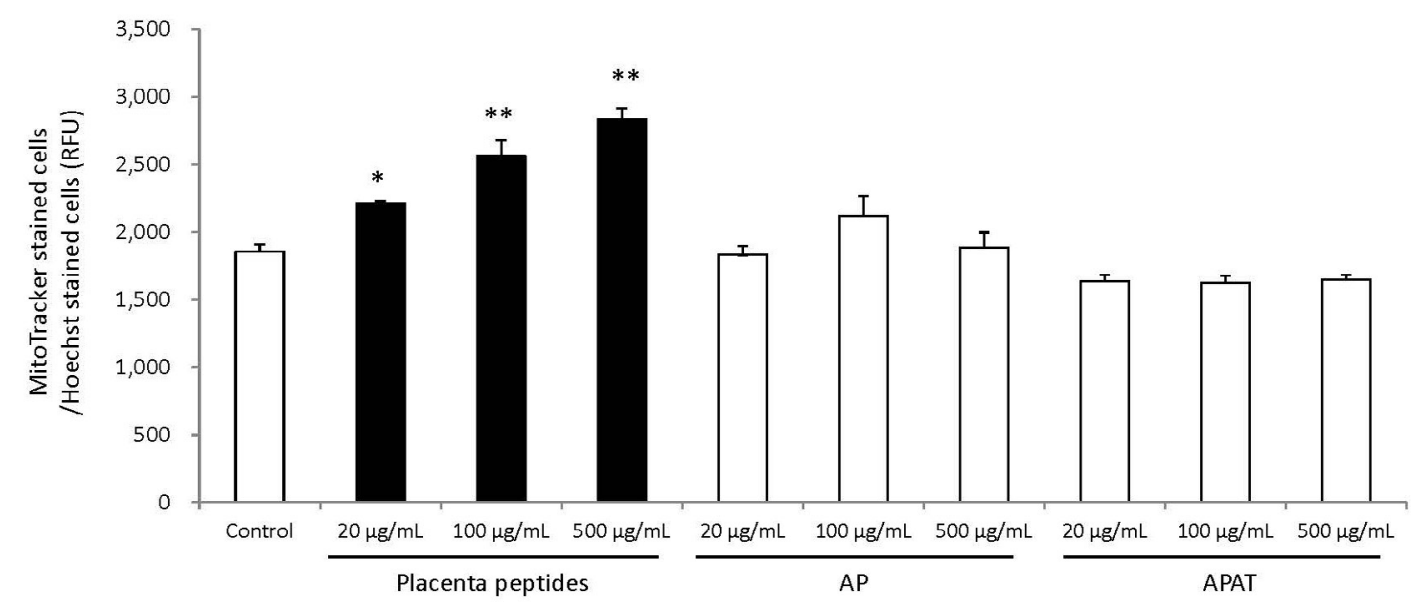

Figure 5. Effects of evaluation for mitochondrial quantity by placenta peptides on 3 days culture.

In placental peptides, mitochondrial abundance increased significantly at all concentrations. On the other hand, no activity was observed in AP (MW; 8,000) and APAT (MW; 60,000) treatment $\mathrm{n}=3$, mean \pm s.d., Dunnett test, $* P<0.05, * * P<0.01$

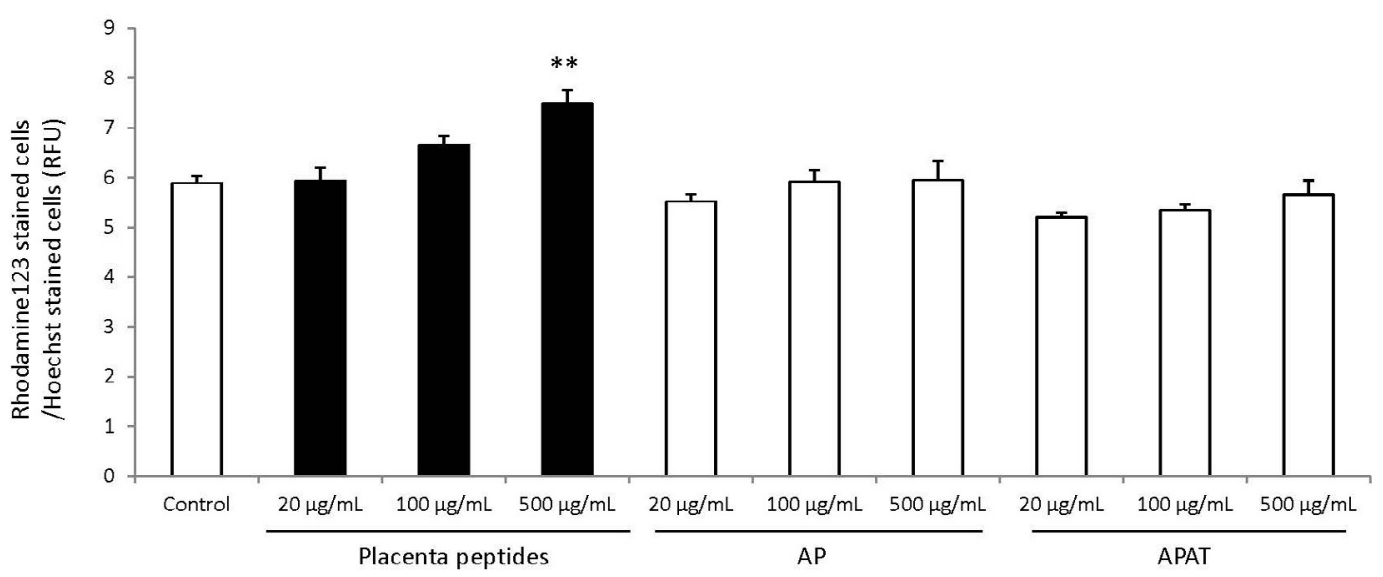

Figure 6. Effects of evaluation for mitochondrial activity by placenta peptides on 7 days culture.

In placental peptides, mitochondrial activity increased significantly at $500 \mu \mathrm{g} / \mathrm{ml}$ concentrations. On the other hand, no activity was observed in AP (MW; 8,000) and APAT (MW; 60,000) treatment. $\mathrm{n}=3$, mean \pm s.d., Dunnett test, $* * P<0.01$

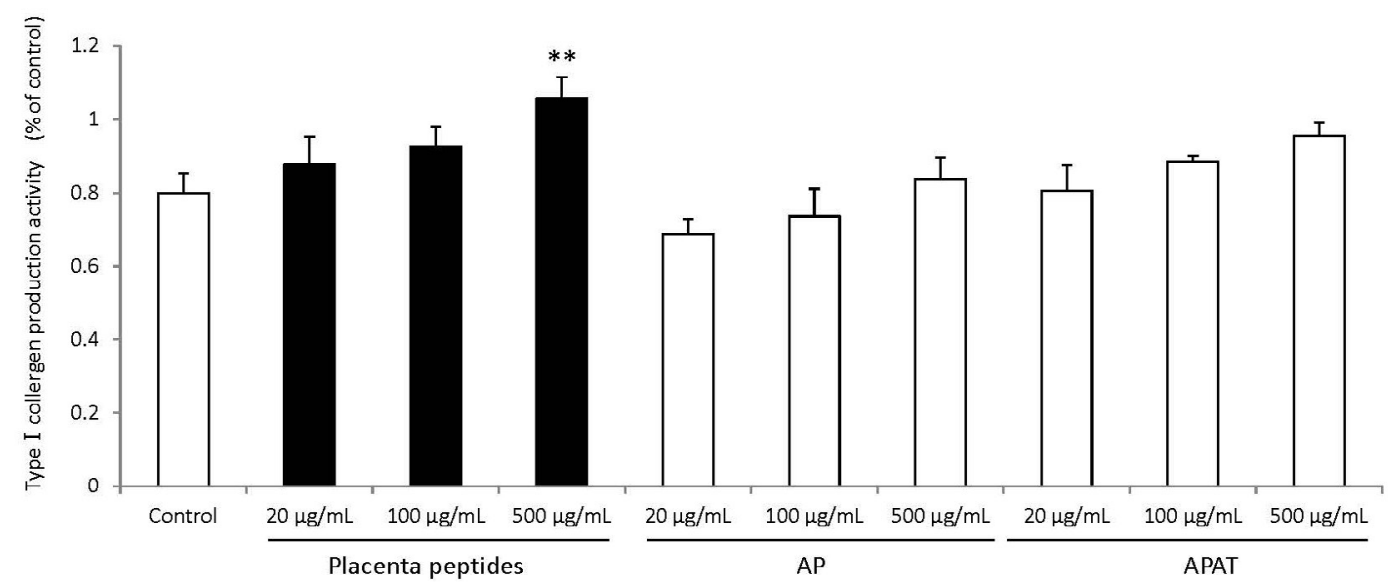

Figure 7. Effects of evaluation for TypeIcollagen production activity by placenta peptides on 14 days culture.

In placental peptides, TypeIcollergen production increased significantly at $500 \mu \mathrm{g} / \mathrm{mL}$ concentrations. On the other hand, no activity was observed in AP (MW; 8,000 ) and APAT (MW; $60,000)$ treatment. $\mathrm{n}=3$, mean \pm s.d., Dunnett test, $* * P<0.01$ 
amino acid sequences with average molecular weights of 3,000 Da stimulate cells using a yet unelucidated mechanism and activate the mitochondria. Mitochondrial proliferation and activation induced by placental peptides may indirectly induce type I collagen production in fibroblasts. Type I collagen produced by fibroblasts is useful for firm bonding between skin cells, thus affecting the firmness of the

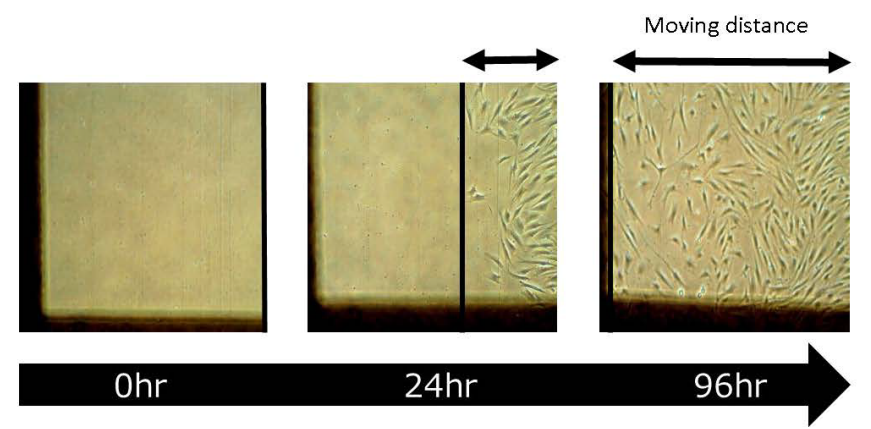

Figure 8. Photographs of wound healing test using human fibroblasts.

This image photos show the migration distance of human fibroblasts stimulated with placental peptides for 96 hours.

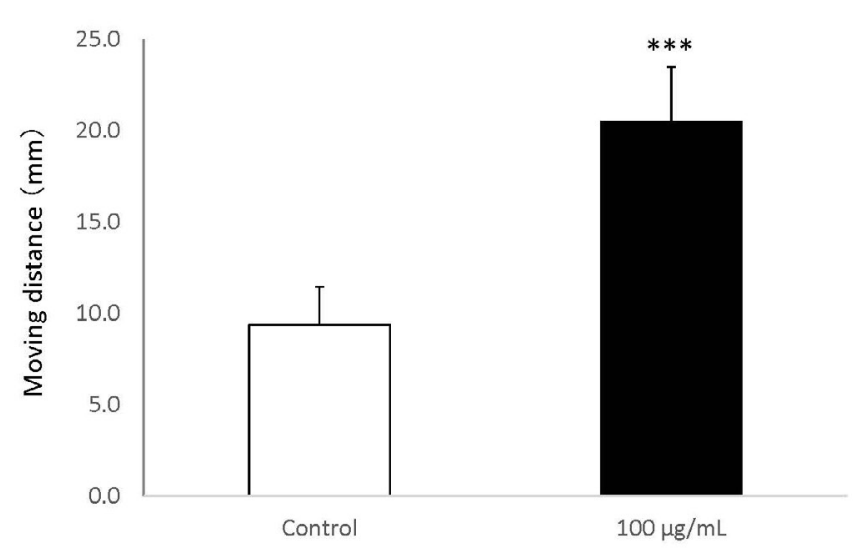

Figure 9. Wound healing test using human fibroblasts.

The migration distance $(\mathrm{mm})$ of when human fibroblasts cells are stimulated with placental peptides $\left(100 \mu \mathrm{g} / \mathrm{mL}\right.$ for 96 hours. $\mathrm{n}=3$, mean \pm s.d., Student's test, ${ }^{* * *} P<0.001$

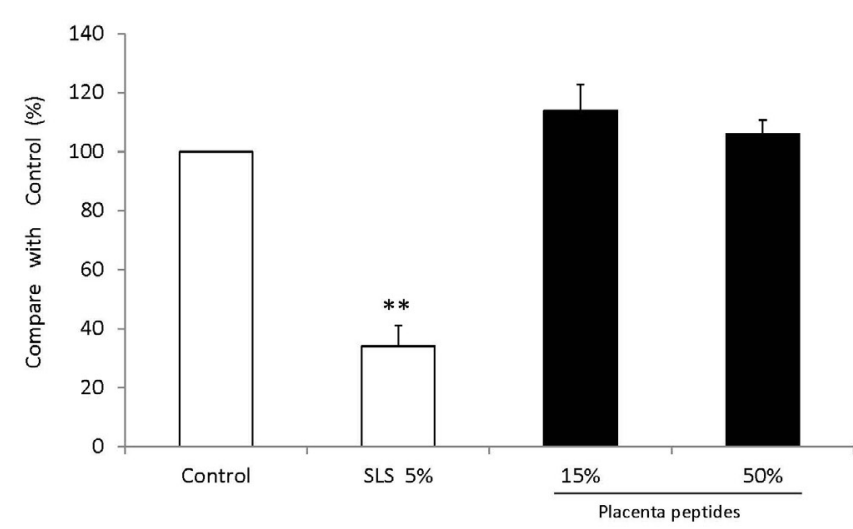

Figure 10. Influence test on three-dimensional human cultured epidermis model.

Placenta peptides prepared to a concentration of $5 \%(\mathrm{~W} / \mathrm{V})$ and $50 \%(\mathrm{~W} / \mathrm{V})$ was added to a human three-dimensional culture epidermis model. As a control of cytotoxic substance, $5 \%$ (W/V) sodium lauryl sulfate (SLS) was added. After 5 days of culture, cell viability was measured by MTT assay. The cells were then incubated with MTT, and the absorbance (OD $540 \mathrm{~nm}$ ) was measured. $\mathrm{n}=3$, mean \pm s.d., Dunnett test, $* * P<0.01$

\section{Control}

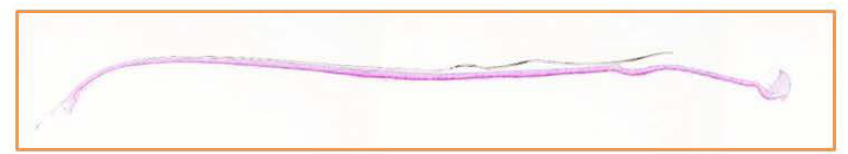

SLS $5 \%$

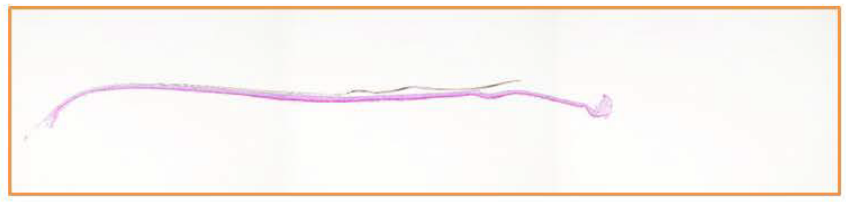

$15 \%$

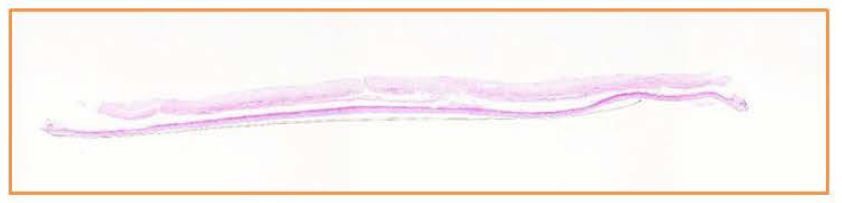

$50 \%$

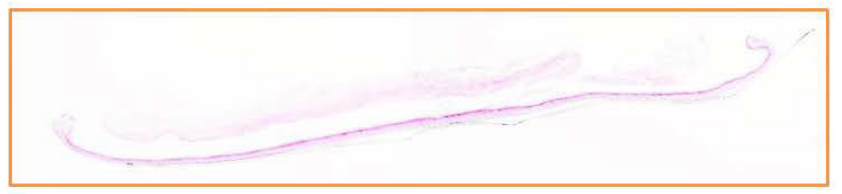

Figure 11. Influence test on three-dimensional human cultured epidermis model.

Placenta peptides prepared to a concentration of $15 \%(\mathrm{~W} / \mathrm{V})$ and $50 \%(\mathrm{~W} / \mathrm{V})$ was added to a human three-dimensional culture epidermis model. As a control of cytotoxic substance, $5 \%$ (W/V) sodium lauryl sulfate (SLS) was added. After 5 days of culture, these photographs are HE staining of tissue and microscopic observation.

skin. Therefore, compounds that induce type I collage production are expected to have an antiwrinkle effect [18-20].

The wound healing assay is an important model for showing early skin repair. A decrease in the migration activity of fibroblasts has been associated with delayed wound healing, and diabetes and aging have been reported to cause a decrease in fibroblast function. Our finding that placental peptides promote the migration of human fibroblasts suggested stimulation of fibroblasts where several factors induce functional degradation and promotion of wound healing effect (barrier effect) on the skin surface [21-25].

The three-dimensional human epidermal culture system, comprising a stratum corneum, granular layer, spinous layer, and a basal layer, is an appropriate model for human skin owing to its similarity to the human skin structure through its highly differentiated and stratified three-dimensional structure, and it is generally used for the evaluation of cosmetic safety (stimulation test) [26].

In this study, addition of placental peptides to the three-dimensional epidermal cultures resulted in cell growth. Therefore, we confirmed the safety and proliferative effect of placental peptides on threedimensional human epidermal cultures, suggesting that application of placental peptides to the skin may result in skin penetration and promotion of skin cell proliferation.

Finally, elimination of reactive oxygen species has been reported to have an antioxidant activity. In the present study, we show that placental peptides have strong antioxidant activities. In addition, they 
are expected to confer UV protective and anti-inflammatory effects when applied in combination with external preparations as cosmetics, thus protecting the skin from damage [27-30].

\section{Conclusion}

We successfully extracted horse placental peptides with unique functions using enzymatic digestion. Particularly, these peptides are expected to function similar to growth factors concerning safety and activation of human fibroblasts. Because peptides are composed of a large number of amino acids, it is extremely challenging to elucidate their entire structure; however, we plan to conduct future studies that investigate the active substance of the horse placental peptides. In conclusion, the placental peptides we obtained through enzymatic digestion are expected to have cosmetic applications.

\section{Acknowledgments}

The present study was supported by the C.B.S Inc. (Sapporo). Molecular weight distribution studies using HPLC were performed by the Japan Food Research Laboratories (Tokyo). Metabolomic analysis was performed by Human Metabolome Technologies, Inc. (Yamagata). In addition, the authors want to thank Mr. Takuya Sezaki at the Shoyaku Kenkyusho Inc. for the valuable discussions and kindly providing the horse placenta.

\section{References}

1. Ansari KU, Gupta N, Bapat SK (1994) An experimental and clinical evaluation of immunomodulating potential of human placental extracts. Ind J Pharmacol 26: 130-132.

2. Chakraborty PD, Bhattacharyya D (2012) Aqueous extract of human placenta as a therapeutic agent. In: Recent Advances in Research on the Human Placenta. Zheng J (ed) InTech, Rijeka, Croatia, pp: 77-92.

3. Chakraborty PD, De D, Bandyopadhyay S, Bhattacharyya D (2009) Human aqueous placental extract as a wound healer. $J$ Wound Care 18: 464-467. [Crossref]

4. Pal P, Mallick S, Mandal SK, Das M, Dutta AK, et al. (2002) A human placental extract: in vivo and in vitro assessments of its melanocyte growth and pigment-inducing activities. Int J Dermatol 41: 760-767. [Crossref]

5. Han NR, Kim KY, Kim MJ, Kim MH, Kim HM, et al. (2013) Porcine placenta mitigates proteinenergy malnutrition-induced fatigue. Nutrition 29: 1381-1387. [Crossref]

6. Koike K, Yamamoto Y, Suzuki N, Yamazaki R, Yoshikawa C, et al. (2012) Efficacy of porcine placental extracts with hormone therapy for postmenopausal women with knee pain. Climacteric 15: 30-35. [Crossref]

7. Mitsui Y, Bagchi M, Marone PA, Moriyama H, Bagchi D (2015) Safety and toxicological evaluation of a novel, fermented, peptide-enriched, hydrolyzed swine placenta extract powder. Toxicol Mech Methods 25: 13-20. [Crossref]

8. Wu CH, Chang GY, Chang WC, Hsu CT, Chen RS (2003) Wound healing effects of porcine placental extracts on rats with thermal injury. Br J Dermatol 148: 236-245. [Crossref]

9. Yoshikawa C, Takano F, Ishigaki Y, Okada M, Kyo S (2013) Effect of porcine placental extract on collagen production in human skin fibroblasts. Gynecol Obstet 3: 1-4.

10. Soga T, Ohashi Y, Ueno Y, Naraoka H, Tomita M, et al. (2003) Quantitative metabolome analysis using capillary electrophoresis mass spectrometry. J Proteome Res 2: 488-494.

11. Sugimoto M, Wong DT, Hirayama A, Soga T, Tomita M (2010) Capillary electrophoresis mass spectrometry-based saliva metabolomics identified oral, breast and pancreatic cancer-specific profiles. Metabolomics 6: 78-95. [Crossref]
12. Bhora FY, Dunkin BJ, Batzri S, Aly HM, Bass BL, et al. (1995) Effect of growth factors on cell proliferation and epithelialization in human skin. J Surg Res 59: 236244. [Crossref]

13. Yahata Y, Shirakata Y, Tokumaru S, Yang L, Dai X et al. (2006) A novel function of angiotensin II in skin wound healing. Induction of fibroblast and keratinocyte migration by angiotensin II via heparin-binding epidermal growth factor (EGF)-like growth factor-mediated EGF receptor transactivation. J Biol Chem 281: 13209-13216. [Crossref]

14. Feng L, Shi N, Cai S, Qiao X, Chu P, et al. (2018) De Novo Molecular Design of a Novel Octapeptide That Inhibits In Vivo Melanogenesis and Has Great Transdermal Ability. J Med Chem 61: 6846-6857. [Crossref]

15. Papagianni P, Varvaresou A, Papageorgiou S, Panderi I (2011) Development and validation of an ion-pair RP-HPLC method for the determination of oligopeptide-20 in cosmeceuticals. J Pharm Biomed Anal 56: 645-649. [Crossref]

16. Bowman A, Birch-Machin MA2 (2016) Age-Dependent Decrease of Mitochondrial Complex II Activity in Human Skin Fibroblasts. J Invest Dermatol 136: 912-919. [Crossref]

17. Kowaltowski AJ (2019) Strategies to detect mitochondrial oxidants. Redox Biol 21 101065. [Crossref]

18. Li Y, Lei D, Swindell WR, Xia W, Wheng S et al. (2015) Age-Associated increase in skin fibroblast-derived prostaglandin E2 contributes to reduced collagen levels in elderly human skin. J Invest Dermatol 135: 2181-2188. [Crossref]

19. Canty EG, Kadler KE (2005) Procollagen trafficking, processing and fibrillogenesis. $J$ Cell Sci 118: 1341-1353. [Crossref]

20. Kondo H, Yonezawa Y, Nomaguchi TA (1990) Difference in migratory ability between human lung and skin fibroblasts. Zool Sci 7: 39-46.

21. Cho HR, Ryou JH, Lee JW, Lee MH (2008) The effects of placental extract on fibroblast proliferation. J Cosmet Sci 59: 195-202. [Crossref]

22. Oh EJ, Kim TK, Shin JH, Choi JH, Chung HY (2011) Biologic filler using human fibroblasts and placenta extracts. J Craniofac Surg 22: 1557-1560. [Crossref]

23. Pal P, Roy R, Datta PK, Dutta AK, Biswas B, et al. (1995) Hydroalcoholic human placental extract: skin pigmenting activity and gross chemical composition. Int $J$ Dermatol 34: 61-66. [Crossref]

24. Elias PM (2007) The skin barrier as an innate immune element. Semin Immunopathol 29 3-14. [Crossref]

25. Slominski A (2007) A nervous breakdown in the skin: stress and the epidermal barrier. $J$ Clin Invest 117: 3166-3169. [Crossref]

26. Itaya Y, Tokudome Y (2016) Upregulation of gene expression levels of ceramide metabolic enzymes after application of sphingomyelin-based liposomes to a threedimensional cultured human epidermis model. Biochem Biophys Res Commun 473: 114-117. [Crossref]

27. Darvin M, Zastrow L, Sterry W, Lademann J (2006) Effect of supplemented and topically applied antioxidant substances on human tissue. Skin Pharmacol Physiol 19: 238-247. [Crossref]

28. Morganti P, Bruno C, Guarneri F, Cardillo A, Del Ciotto P, et al. (2002) Role of topical and nutritional supplement to modify the oxidative stress. Int J Cosmet Sci 24: 331339. [Crossref]

29. Togashi S, Takahashi N, Iwama M, Watanabe S, Tamagawa K, et al. (2002) Antioxidative collagen-derived peptides in human-placenta extract. Placenta 23: 497502. [Crossref]

30. Nanjo F, Goto K, Seto R, Suzuki M, Sakai M, et al. (1996) Scavenging effects of tea catechins and their derivatives on 1,1-diphenyl-2-picrylhydrazyl radical. Free Radic Biol Med 21: 895-902. [Crossref]

Copyright: (C2019 Wakame K. This is an open-access article distributed under the terms of the Creative Commons Attribution License, which permits unrestricted use, distribution, and reproduction in any medium, provided the original author and source are credited. 